\title{
PDRB Hijau dalam Perkembangan Wilayah di Kota Depok
}

\author{
The Green GRDP in The Regional Development of Depok City \\ Setyo Nugroho ${ }^{1}$, Kukuh Murtilaksono ${ }^{2}$, dan Soekmana Soma ${ }^{2}$
}

Diterima: 6 Maret 2019

Disetujui: 19 November 2019

\begin{abstract}
Abstrak: Kota Depok telah menjadi salah satu kota dengan pertumbuhan ekonomi yang tinggi di Provinsi Jawa Barat. Namun, pertumbuhan tinggi ini memiliki dampak terhadap lingkungan. Penelitian ini bertujuan untuk mengkaji tingkat perkembangan wilayah, mengkaji keterkaitan antar sektor ekonomi, dan menghitung PDRB hijau untuk arahan pengembangan wilayah. Penggunaan metode skalogram dan analisis input output (IO) untuk menunjukkan tingkat perkembangan wilayah dan mengidentifikasi sektor kunci. Adapun nilai PDRB hijau didapatkan dari perhitungan deplesi sumberdaya alam dan degradasi lingkungan. Penelitian menunjukkan bahwa 65,08\% kelurahan di Kota Depok berbentuk hinterland. Selain itu, sektor listrik, gas, dan air minum adalah sektor kunci pembangunan ekonomi di Kota Depok. Selanjutnya, nilai PDRB Hijau hanya memiliki selisih 4,47\% atau Rp2.610,78 miliar, dibandingkan dengan PDRB Coklat. Namun, jika selisih PDRB tersebut dibandingkan dengan pendapatan asli daerah (PAD) akan menghabiskan seluruh pendapatan. Hasil analisis menyimpulkan bahwa PDRB hijau lebih relevan untuk digunakan sebagai indikator ekonomi karena lebih menggambarkan tingkat kesejahteraan seutuhnya.
\end{abstract}

Kata kunci: skalogram, analisis input output, deplesi, degradasi, PDRB hijau

\begin{abstract}
Depok City has become one of the cities with high economic growth in West Java Province. This high growth, however, also has impact on the environment. This study aimed to review the level of regional development and linkages among economic sectors and calculate Green GRDP for regional development directions. Scalogram method and input output analysis were applied to indicate the level of regional development and identify the key sectors. The value of green GRDP was obtained from the calculation of natural resource depletion and calculation of environmental degradation. The research showed that $65.08 \%$ of villages in Depok City were in the form of hinterland. The sector of electricity, gas, and drinking water was the key sector of economic development in Depok City. Furthermore, the Green GRDP value only had a difference of $4.47 \%$ or Rp2,610.78 billion, compared to Brown GRDP. However, if the GRDP difference was compared to the original local government revenue, this would consume all of the income. The analysis resulted green GRDP was more relevant to be applied as an economic indicator because better description the level of overall welfare.
\end{abstract}

Keywords: scalogram, input output analysis, depletion, degradation, green GRDP

\footnotetext{
${ }^{1}$ Program Studi Ilmu Perencanaan Wilayah, Sekolah Pascasarjana IPB

${ }^{2}$ Departemen Ilmu Tanah dan Sumberdaya Lahan, Fakultas Pertanian, IPB
} 


\section{PENDAHULUAN}

Pengelolaan lingkungan hidup merupakan suatu tantangan dalam proses pembangunan. World Bank (2009), menyebutkan bahwa terbatasnya akses pada air bersih dan sanitasi diperkirakan bisa merugikan ekonomi Indonesia antara 2,5-7\% dari Produk Domestik Bruto (PDB) sampai dengan akhir abad ini. Total biaya degradasi lingkungan, termasuk perubahan iklim, mencapai 5\% dari PDB per tahun dan memiliki kecenderungan untuk terus meningkat.

Merujuk pada data BPS (2018), Produk Domestik Regional Bruto (PDRB) Jawa Barat atas dasar harga berlaku, pada tahun 2013-2017 selalu berada pada tingkat ketiga penyumbang terbesar PDB. Berbeda jika memperhatikan Indeks Kualitas Lingkungan Hidup (IKLH) pada tahun 2016 yang menunjukkan nilai IKLH sebesar 51,87 atau peringkat ketiga terbawah di atas DKI Jakarta dan Yogyakarta (KLHK, 2017).

Sebagai salah satu kota yang terdapat di Provinsi Jawa Barat, Kota Depok telah menjadi salah satu kota yang pesat pertumbuhan ekonominya. Laju pertumbuhan ekonomi yang tinggi ini dapat terjadi saat keterkaitan antar sektor cukup berkembang. Namun pertumbuhan tersebut juga dapat memiliki dampak terhadap lingkungan. Berdasarkan pengujian emisi gas buang kendaraan, terdapat peningkatan 40,81 persen kendaraan dari tahun 2014-2016 (BPS Kota Depok, 2017), berarti mengindikasikan bertambahnya penggunaan bahan bakar minyak (BBM). Penggunaan bahan bakar dapat mengemisikan zat pencemar yang menyebabkan gangguan kesehatan pada pembuluh darah dan paruparu (Ismiyati et al., 2014). Adapun pada tahun 2016, jumlah sampah yang diproduksi di Kota Depok setiap harinya berjumlah 1.286 ton sampah dengan jumlah yang dapat dilayani Pemerintah Kota (Pemkot) Depok sebanyak 735 ton/hari, sehingga terdapat 551 ton/hari atau $43,78 \%$ di luar pengelolaan Pemkot yang dapat menyebabkan terciptanya tempat pembuangan sampah liar (Paramita, 2018).

Sejalan dengan itu, kebersihan menjadi tuntutan karena dengan semakin meningkatnya konsumsi, masyarakat juga menginginkan lingkungan yang bersih, sampah yang terkelola dengan baik, dan berbagai kebutuhan layanan kota lainnya. Dengan demikian kebutuhan akan informasi kelengkapan fasilitas serta kemudahan dalam mengaksesnya menjadi penting, sehingga penentuan tingkat perkembangan wilayah dapat digunakan sebagai informasi dalam prioritas pembangunan fasilitas. Disisi lain, perlu juga tetap menjaga laju pertumbuhan ekonomi melalui pengembangan sektor strategis agar efisien, salah satunya dengan cara memperhatikan keterkaitan antar sektor ekonominya.

Laju pertumbuhan ekonomi yang salah satunya memperhatikan PDRB sebagai salah satu indikator makro ekonomi, selama ini seringkali hanya memasukkan hasil kegiatan ekonomi yang baik saja, namun meniadakan barang yang rusak atau mencemari (Ratnaningsih et.al, 2006). PDRB konvensional belum mencerminkan nilai kesejahteraan sesungguhnya karena pendapatan dapat saja meningkat tetapi aset semakin menipis, hal ini disebabkan PDRB konvensional hanya mencerminkan nilai kontribusi produk yang dipasarkan, belum terintegrasi unsur deplesi sumberdaya alam dan degradasi lingkungan (Putra, 2013). Beberapa penelitian telah memasukkan dimensi lingkungan yang terdiri dari nilai deplesi sumberdaya alam dan nilai degradasi lingkungan sebagai pos penyusutan (depresiasi) sumberdaya alam ke dalam penghitungan PDRB sehingga dapat dihasilkan nilai kontribusi hijau atau disebut juga sebagai PDRB hijau (Setyarko, 2008 dan Utama, 2009).

Uraian ini semua dapat memberikan rambu-rambu bahwa aspek lingkungan perlu diperhatikan agar perkembangan wilayah dapat dibangun berkelanjutan. Melalui penelitian ini, dilakukan identifikasi sektor strategis dengan memperhatikan keterkaitan antar sektor ekonomi serta mengidentifikasi kelengkapan fasilitas wilayah. Selanjutnya bersama dengan perhitungan PDRB hijau, digunakan sebagai dasar pertimbangan dalam melakukan pengembangan wilayah yang berwawasan lingkungan di Kota Depok, yang terangkum dalam tujuan penelitian yaitu (1) mengkaji tingkat perkembangan wilayah di Kota Depok, 
(2) mengkaji keterkaitan antar sektor yang terjadi dalam perekomian di Kota Depok, dan

(3) Melakukan perhitungan PDRB Hijau untuk arahan pengembangan wilayah di Kota Depok

\section{METODE PENELITIAN}

\section{Lokasi dan Waktu Penelitian}

Penelitian dilaksanakan di Kota Depok dengan titik koordinat pada $6^{0} 19^{\prime} 00^{\prime \prime}-6^{0}$ $28^{\prime} 00^{\prime \prime}$ LS dan $106^{0} 43^{\prime} 00^{\prime \prime}-106^{0} 55^{\prime} 30^{\prime \prime}$ BT. Wilayah Kota Depok seluas 200,29 km² yang merupakan daerah dataran rendah dengan ketinggian 50-140 meter diatas permukaan laut (DPL) dan dataran rendah perbukitan bergelombang lemah. Penelitian ini dilaksanakan pada bulan Mei 2018 hingga Januari 2019.

\section{Bahan dan Alat}

Bahan yang digunakan berupa data sekunder yang diperoleh dari DLHK Kota Depok, DPMPTSP Kota Depok, DKUM Kota Depok, BPS, BPS Provinsi Jawa Barat, BPS Kota Depok, dan Instansi Pengelola SDA. Alat yang digunakan terdiri dari alat tulis, software ArcGIS 10.2, dan Microsoft Office.

\section{Teknik Analisis Data} berikut.

Teknik analisis data yang digunakan untuk menjawab tujuan penelitian yaitu sebagai

\section{Analisis Tingkat Perkembangan Wilayah}

Tingkat perkembangan wilayah dihitung dengan metode skalogram yang dikembangkan Rustiadi dan Panuju (2013) sebagai bentuk penyempurnaan atas metode skalogram yang sudah dikembangkan sebelumnya. Variabel dibagi menjadi dua kelompok yakni variabel positif dan negatif, dengan persamaan sebagai berikut:

Dimana,

$$
K_{i j}=\frac{\left(X_{i j}-\min \left(X_{j}\right)\right)}{S_{j}}
$$

$\begin{array}{ll}\mathrm{K}_{\mathrm{ij}} & =\text { nilai baku indeks hirarki untuk wilayah ke-i dan ciri ke-j; } \\ \mathrm{X}_{\mathrm{ij}} & =\text { nilai bobot indeks penciri untuk wilayah ke-i dan ciri ke-j; } \\ \min \left(\mathrm{X}_{\mathrm{j}}\right) & \quad=\text { nilai minimum indeks pada ciri ke-j; } \mathrm{S}_{\mathrm{j}}=\text { nilai standar deviasi. }\end{array}$

\section{Metode RAS}

Metode RAS digunakan untuk memperkirakan koefisien input pada periode $t$, dengan cara balancing nilai baris permintaan dan penyediaan dan kolom input-output, dengan rumus (Miller dan Blair, 1985 dalam Daryanto dan Hafizrianda, 2013):

$$
A(t)=R \cdot A(0) \cdot S
$$

Dimana,

$\mathrm{A}(\mathrm{t}) \quad=$ Matriks sektor yang berukuran $n \times n$ pada periode $\mathrm{t}$;

$\mathrm{A}(0) \quad=$ Matriks sektor yang berukuran $n \times n$ pada periode 0 ;

$\mathrm{R} \quad=$ Matriks diagonal mewakili efek substitusi teknologi yang diukur melalui jumlah permintaan antara;

$\mathrm{S} \quad=$ Matriks diagonal mewakili efek perubahan jumlah input antara.

Pada penelitian ini menggunakan tabel input-output dengan matrik sektor ekonomi berukuran $42 \times 42$. 


\section{Analisis Input Output}

Analisis input output lebih menekankan pada keterkaitan antar sektor ekonomi yang terdiri dari (Rustadi et al, 2009 dalam Darlen et al., 2015):

1. Keterkaitan langsung ke belakang (direct backward linkage/ $\mathrm{Bj}$ ), merupakan efek permintaan suatu sektor terhadap perubahan tingkat produksi sektor-sektor yang menyediakan input antara untuk sektor tersebut secara langsung, yaitu melalui penjumlahan tiap kolom $a_{i j}$ di tiap kolom $j$.

$$
B_{j}=\sum_{j}^{n} a_{i j}
$$

2. Keterkaitan langsung ke depan (direct forward linkage/ Fi), menunjukkan banyaknya output suatu sektor yang digunakan oleh sektor lain dalam produksinya.

$$
F_{i}=\sum_{j}^{n} a_{i j}
$$

Adapun untuk menunjukkan kekuatan relatif permintaan akhir suatu sektor dalam mendorong pertumbuhan produksi total seluruh sektor perekonomian dapat melalui indeks daya penyebaran (backward power of dispersion $/ \beta \mathrm{j}$ ), dengan rumus:

$$
\beta_{j}=\frac{n \sum_{i} b_{i j}}{\sum_{i} \quad \sum_{j} b_{j}}
$$

Jika $\beta \mathrm{j}>1$, maka menunjukkan permintaan akhir sektor $\mathrm{j}$ dalam merangsang pertumbuhan produksi secara relatif lebih besar dari rata-rata.

Untuk menunjukkan sumbangan relatif suatu sektor dalam memenuhi permintaan akhir keseluruhan sektor perekonomian, dapat dilakukan dengan menghitung indeks daya kepekaan/forward power of dispersion $\left(\alpha_{\mathrm{i}}\right)$, melalui rumus.

$$
\alpha_{i}=\frac{\sum_{j} b_{j}}{\frac{1}{n} \sum_{i} \quad \sum_{j} b_{j}}
$$

Jika $\alpha_{i}>1$, maka dapat menujukkan suatu sektor yang strategis karena secara relatif dapat memenuhi permintaan akhir di atas kemampuan rata-rata.

\section{Perhitungan Penyusutan (Deplesi) Sumberdaya Alam}

Perhitungan deplesi sumberdaya alam (SDA) dilakukan dengan langkah-langkah sebagai berikut (Ratnaningsih et al., 2006):

1. Identifikasi penggunaan SDA yang dimanfaatkan setiap sektor.

2. Kuantifikasi volume SDA yang terdeplesi dengan pengambilan data berupa jenis dan volume tiap sektor.

3. Valuasi ekonomi SDA yang terdeplesi dengan mengalikan volume pengambilan masing-masing jenis sumberdaya alam dengan unit rent, rumusnya:

$$
\mathrm{D}=\mathrm{Q} \times \mathrm{U}
$$

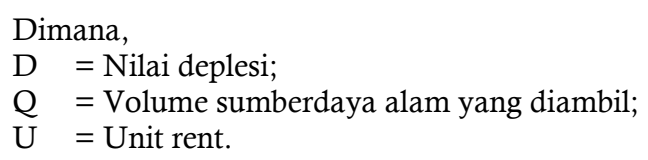




\section{Perhitungan Degradasi Lingkungan}

Menurut Ratnaningsih et al. (2012) dalam Mulya et al. (2014), langkah-langkah dalam menghitung degradasi lingkungan adalah sebagai berikut:

1. Identifikasi kerusakan SDA maupun lingkungan yang terjadi.

2. Kuantifikasi fisik degradasi lingkungan baik SDA atau lingkungan terdegradasi.

3. Valuasi ekonomi terhadap degradasi lingkungan, dimana pendekatan yang umum digunakan dalam kaitannya dengan penyusunan PDRB hijau adalah pendekatan replacement costs (Suparmoko et al., 2014). Garrod dan Willis (1999) dalam Hifdziyah (2011), memberikan formula perhitungan pendekatan biaya pengganti sebagai berikut:

$$
B P=P \times Q D
$$

dimana $\mathrm{BP}=$ Biaya pengganti; $\mathrm{P}=$ Harga barang; $\mathrm{U}=$ Kuantitas barang yang rusak .

Selain itu, valuasi ekonomi pada penelitian ini menggunakan metode cost of illness yang terdiri dari opportunity cost yaitu biaya yang diakibatkan tidak dapat bekerja dan currative cost atau biaya penyembuhan.

\section{Perhitungan PDRB Hijau}

PDRB Hijau secara singkat dapat dihitung melalui langkah-langkah sebagai berikut (Ratnaningsih et al., 2006):

1. Menghitung PDRB Coklat.

2. PDRB Coklat dikurangi deplesi sumberdaya alam disebut PDRB Semi Hijau.

3. PDRB Semi Hijau dikurangi degradasi lingkungan disebut sebagai PDRB Hijau.

\section{HASIL DAN PEMBAHASAN}

\section{Tingkat Perkembangan Wilayah}

Dari hasil analisis skalogram, diketahui bahwa sebagian besar kelurahan di Kota Depok berada pada tingkat perkembangan yang rendah atau hirarki III. Dari 63 kelurahan yang dianalisis, terdapat hanya 10 kelurahan atau sekitar 15,87 persen yang termasuk dalam Hirarki I dan kelurahan yang diidentifikasi sebagai wilayah hirarki II berjumlah 12 kelurahan atau sekitar 19,05 persen. Adapun selebihnya berada pada Hirarki III yaitu sebanyak 41 kelurahan atau sekitar 65,08 persen dari seluruh kelurahan yang dianalisis, seperti pada Gambar 1.

Terdapat kelurahan-kelurahan yang menjadi pusat, terkumpul pada kawasan tertentu karena berada berdekatan dengan kawasan strategis di Kota Depok dari sudut pandang ekonomi yaitu Kawasan Margonda yang identik dengan nama jalan di sepanjang wilayah ini. Adapun wilayah pusat lainnya berkembang lebih diakibatkan oleh pertumbuhan kawasan permukiman diwilayahnya.

Penelitian Sudarya et al. (2013) di wilayah pesisir Kabupaten Garut, menjadikan wilayah hirarki I dan hirarki II sebagai daerah inti sedangkan wilayah hirarki III sebagai daerah hinterland dimana fokus pembangunan diprioritaskan pada pembangunan sumberdaya alam terutama di sektor primer. Namun kondisi Kota Depok sebagaimana kawasan perkotaan pada umumnya, sangat sulit mengembangkan wilayah yang berfokus pada pembangunan sarana produksi dalam mendukung sektor primer yang relatif sangat minim. Oleh karena itu, perlu mengembangkan sarana yang berorientasi pada sektor sekunder dan tersier untuk mendukung potensi kelurahan hirarki III.

Khusus melihat fasilitas terkait dengan lingkungan hidup yang pada penelitian ini menggunakan data berupa fasilitas kebersihan untuk pengelolaan sampah. Oleh karena itu, keberadaan fasilitas layanan kebersihan sampah dapat menjadi perhatian dalam pengembangan wilayah. Melalui pengelolaan sampah yang baik, tidak akan mengakibatkan perubahan keseimbangan lingkungan yang tidak diharapkan bahkan 
merugikan (Wibisono dan Dewi, 2014). Lebih jauh lagi, Moersid (2004) dalam Tampuyak et al. (2016) menyatakan permasalahan pengelolaan sampah menjadi sangat serius diperkotaan akibat kompleksnya permasalahan dan kepadatan penduduk yang tinggi. Berarti pembangunan fasilitas layanan kebersihan sampah di wilayah perkotaan seperti Kota Depok dapat memprioritaskan pembangunannya pada wilayah yang padat penduduk.

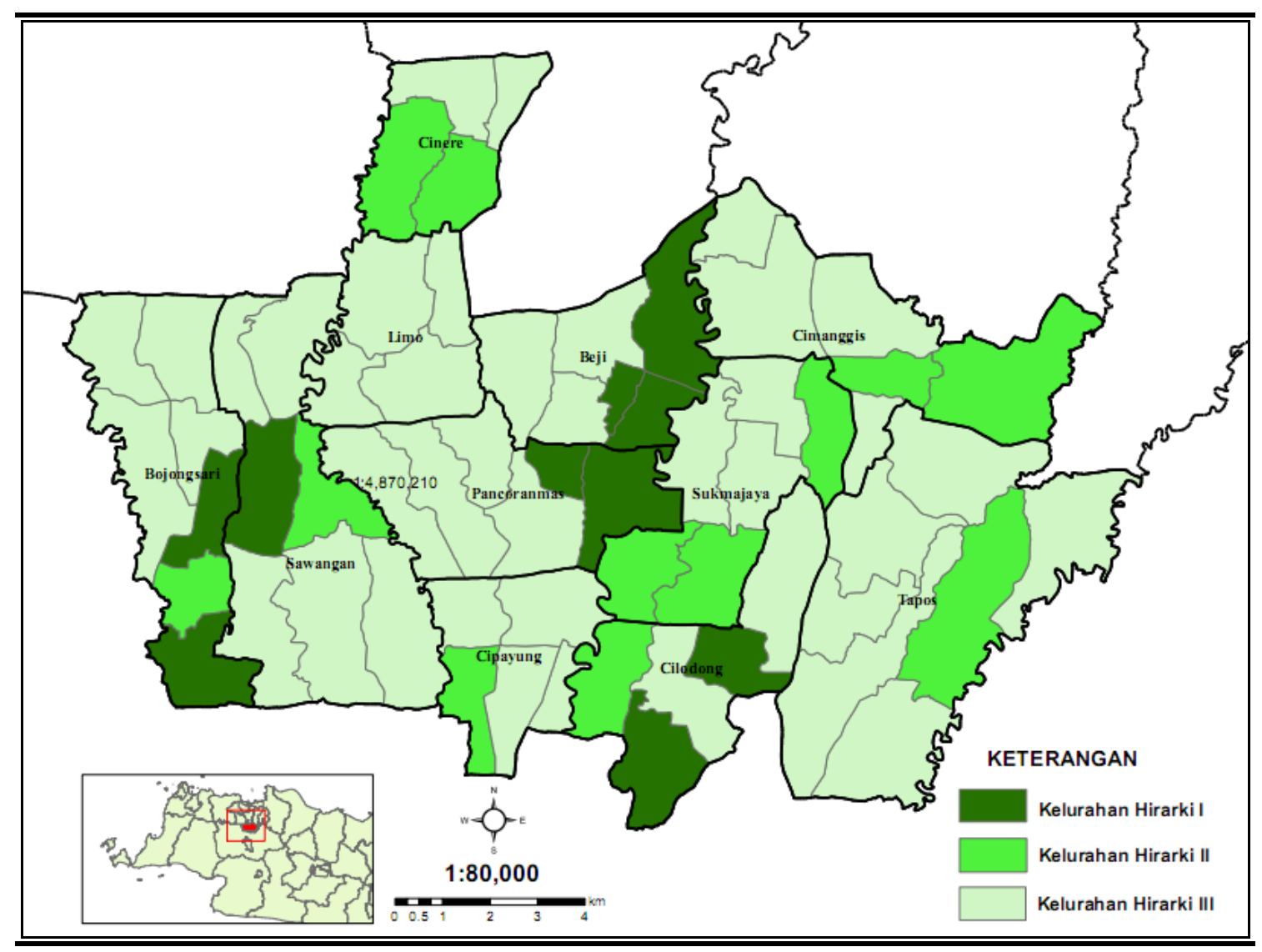

Gambar 1 Peta Hirarki Perkembangan Wilayah Kelurahan di Kota Depok

\section{Keterkaitan Antar Sektor Ekonomi}

Setelah dilakukan penyesuaian melalui metode RAS terhadap tabel input-output tahun 2015 yang menghasilkan tabel input-output tahun 2017 hasil RAS dengan sektor ekonomi sebanyak 42 sektor. Selanjutnya dilakukan analisis keterkaitan antar sektor ekonomi yaitu:

\section{Keterkaitan ke Belakang antar Sektor Ekonomi}

Hasil analisis keterkaitan langsung ke belakang menunjukkan bahwa sektor yang mempunyai nilai relatif besar adalah Sektor pertanian tanaman lainnya dan Sektor industri rokok. Melihat pada sepuluh sektor yang memiliki keterkaitan ke belakang tertinggi, menunjukkan bahwa sebagian besarnya merupakan bagian dari sektor industri pengolahan. Keadaan ini menggambarkan sektor industri pengolahan memiliki pengaruh yang tinggi dalam memberikan dampak pada perekonomian di Kota Depok.

Apabila melihat hubungan tiap-tiap sektor, menunjukkan bahwa perekonomian Kota Depok sangat dipengaruhi oleh Sektor Perdagangan (Tabel 1). Hal ini mengindikasikan bahwa dampak ekonomi akan lebih berpengaruh terhadap kenaikan output Sektor 
perdagangan yang merupakan sektor usaha yang berfokus pada transaksi barang/ jasa dan bertujuan mengalihkan hak atas barang untuk memperoleh imbalan. Sektor perdagangan mendominasi perekonomian karena sebagian besar pertumbuhan pada suatu sektor ekonomi di Kota Depok akan melibatkan sektor ini dalam mensuplai inputnya. Adapun dengan tidak tercatatnya Sektor pertambangan dan penggalian di Kota Depok, maka semestinya melalui Sektor perdagangan inilah bahan baku berupa sumberdaya alam diperoleh dari luar Kota Depok. Oleh karena itu, meskipun sektor industri menyumbangkan nilai tertinggi pada PDRB, namun sumberdaya alam yang diekstraksi langsung dari dalam Kota Depok relatif sedikit.

Tabel 1. Sepuluh Sektor dengan Nilai Keterkaitan Langsung ke Belakang Tertinggi di Kota Depok Tahun 2017 Hasil RAS

\begin{tabular}{|c|c|c|c|c|}
\hline \multirow{2}{*}{ No } & \multirow{2}{*}{ Uraian Sektor } & \multicolumn{2}{|c|}{$\begin{array}{c}\text { Nilai Keterkaitan Tertinggi } \\
\text { dengan Sektor Lainnya }\end{array}$} & \multirow{2}{*}{$\begin{array}{c}\text { Total Nilai } \\
\text { Keterkaitan Ke } \\
\text { Belakang }\end{array}$} \\
\hline & & Sektor Lainnya & $\begin{array}{c}\text { Nilai } \\
\text { Keterkaitan }\end{array}$ & \\
\hline 1 & Pertanian Tanaman Lainnya & Perdagangan & 1.00000 & 1.00000 \\
\hline 2 & Industri Rokok & Perdagangan & 0.93247 & 0.93812 \\
\hline 3 & Industri Dasar Besi dan Baja & Perdagangan & 0.47227 & 0.53794 \\
\hline 4 & Listrik, Gas, dan Air Minum & $\begin{array}{l}\text { Bank dan } \\
\text { Asuransi }\end{array}$ & 0,08882 & 0.53479 \\
\hline 5 & Industri Logam Dasar Bukan Besi & Perdagangan & 0.46736 & 0.53364 \\
\hline 6 & Industri Barang dari Logam & Perdagangan & 0.46384 & 0.53055 \\
\hline 7 & Real Estate dan Jasa Perusahaan & Konstruksi & 0,29333 & 0.35409 \\
\hline 8 & Industri Penggilingan Padi & Perdagangan & 0.24613 & 0.31271 \\
\hline 9 & $\begin{array}{l}\text { Industri Barang-Barang Dari Mineral } \\
\text { Bukan Logam }\end{array}$ & Perdagangan & 0.10039 & 0.30374 \\
\hline 10 & Industri Semen & Perdagangan & 0.09931 & 0.30199 \\
\hline
\end{tabular}

\section{Keterkaitan ke Depan antar Sektor Ekonomi}

Sektor perdagangan menjadi sektor ekonomi yang memiliki nilai keterkaitan langsung ke depan tertinggi di Kota Depok mencapai 5,34759. Dominasi sektor Perdagangan pada hasil analisis keterkaitan langsung ke depan menunjukkan bahwa sektor ini merupakan bagian penting dalam rantai perekonomian di Kota Depok. Namun jika melihat lebih luas, maka dari sisi jumlah terlihat bahwa sektor Listrik, Gas, dan Air Minum menjadi sektor yang memiliki keterkaitan langsung ke depan yang paling banyak (Tabel 2). Hal ini menunjukkan bahwa jika terdapat kenaikan pada suatu sektor ekonomi, maka sektor Listrik, Gas, dan Air Minum menjadi sektor yang memiliki keterkaitan langsung ke depan paling banyak, sehingga relatif paling sering terpengaruh dalam peningkatan outputnya.

Tabel 2. Sepuluh Sektor dengan Nilai Keterkaitan Langsung ke Depan Tertinggi di Kota Depok Tahun 2017 Hasil RAS

\begin{tabular}{lllcc}
\hline \multirow{2}{*}{ No } & \multicolumn{1}{c}{ Uraian Sektor } & \multicolumn{2}{c}{ Nilai Keterkaitan Tertinggi dengan Sektor Lainnya } & Total Nilai \\
\cline { 3 - 4 } & & \multicolumn{1}{c}{ Sektor Lainnya } & $\begin{array}{c}\text { Nilai } \\
\text { Keterkaitan } \\
\text { Ke Depan }\end{array}$ \\
\hline 1 & Perdagangan & Pertanian Tanaman Lainnya & 1.00000 & 5.34759 \\
2 & Bank dan Asuransi & Listrik, Gas Dan Air Minum & 0.08882 & 0.51831 \\
3 & Industri kimia & Industri barang-barang dari & 0.07852 & 0.44792 \\
& & mineral bukan logam & \\
4 & Konstruksi & Real Estate dan Jasa Perusahaan & 0.29333 & 0.44272 \\
5 & Jasa Perseorangan, Rumah & Listrik, Gas Dan Air Minum & 0.08241 & 0.41103
\end{tabular}

tangga dan Jasa Lainnya 


\begin{tabular}{|c|c|c|c|c|}
\hline \multirow[b]{2}{*}{ No } & \multirow[b]{2}{*}{ Uraian Sektor } & \multicolumn{2}{|c|}{ Nilai Keterkaitan Tertinggi dengan Sektor Lainnya } & \multirow{2}{*}{$\begin{array}{c}\text { Total Nilai } \\
\text { Keterkaitan } \\
\text { Ke Depan }\end{array}$} \\
\hline & & Sektor Lainnya & $\begin{array}{c}\text { Nilai } \\
\text { Keterkaitan }\end{array}$ & \\
\hline 6 & $\begin{array}{l}\text { Listrik, Gas Dan Air } \\
\text { Minum }\end{array}$ & Konstruksi & 0.02971 & 0.33762 \\
\hline 7 & $\begin{array}{l}\text { Industri barang karet dan } \\
\text { plastik }\end{array}$ & $\begin{array}{l}\text { Industri barang-barang dari } \\
\text { mineral bukan logam }\end{array}$ & 0.04418 & 0.27743 \\
\hline 8 & $\begin{array}{l}\text { Angkutan Udara, Air dan } \\
\text { Komunikasi }\end{array}$ & $\begin{array}{l}\text { Jasa Penunjang Angkutan, dan } \\
\text { Pergudangan }\end{array}$ & 0.06659 & 0.23804 \\
\hline 9 & $\begin{array}{l}\text { Industri mesin, alat-alat dan } \\
\text { perlengkapan listrik }\end{array}$ & Listrik, Gas Dan Air Minum & 0.06309 & 0.21039 \\
\hline 10 & $\begin{array}{l}\text { Industri barang lain yang } \\
\text { belum digolongkan } \\
\text { dimanapun }\end{array}$ & $\begin{array}{l}\text { Industri barang lain yang belum } \\
\text { digolongkan dimanapun }\end{array}$ & 0.07245 & 0.17939 \\
\hline
\end{tabular}

\section{Daya Penyebaran dan Derajat Kepekaan}

Pengembangan sektor ekonomi di Kota Depok dapat menempatkan Sektor Listrik, Gas, dan Air Minum sebagai sektor kunci pembangunan ekonomi Kota Depok, dikarenakan memiliki nilai Indeks Daya Penyebaran (IDP) dan Indeks Derajat Kepekaan (IDK) tinggi yang masing-masing memiliki nilai sebesar 1,27686 dan 1,18117, seperti diperlihatkan Gambar 2. Pengembangan sektor ini diharapkan dapat merangsang pertumbuhan produksi sektor-sektor ekonomi secara total, sekaligus meningkatkan pemenuhan permintaan akhir sektor-sektor. Besarnya pengaruh perusahaan-perusahaan utama pada Sektor listrik, gas, dan air minum menjadikan pengembangan wilayah pada sektor kunci juga harus memperhatikan kewenangan yang dimiliki oleh PLN dan PDAM.

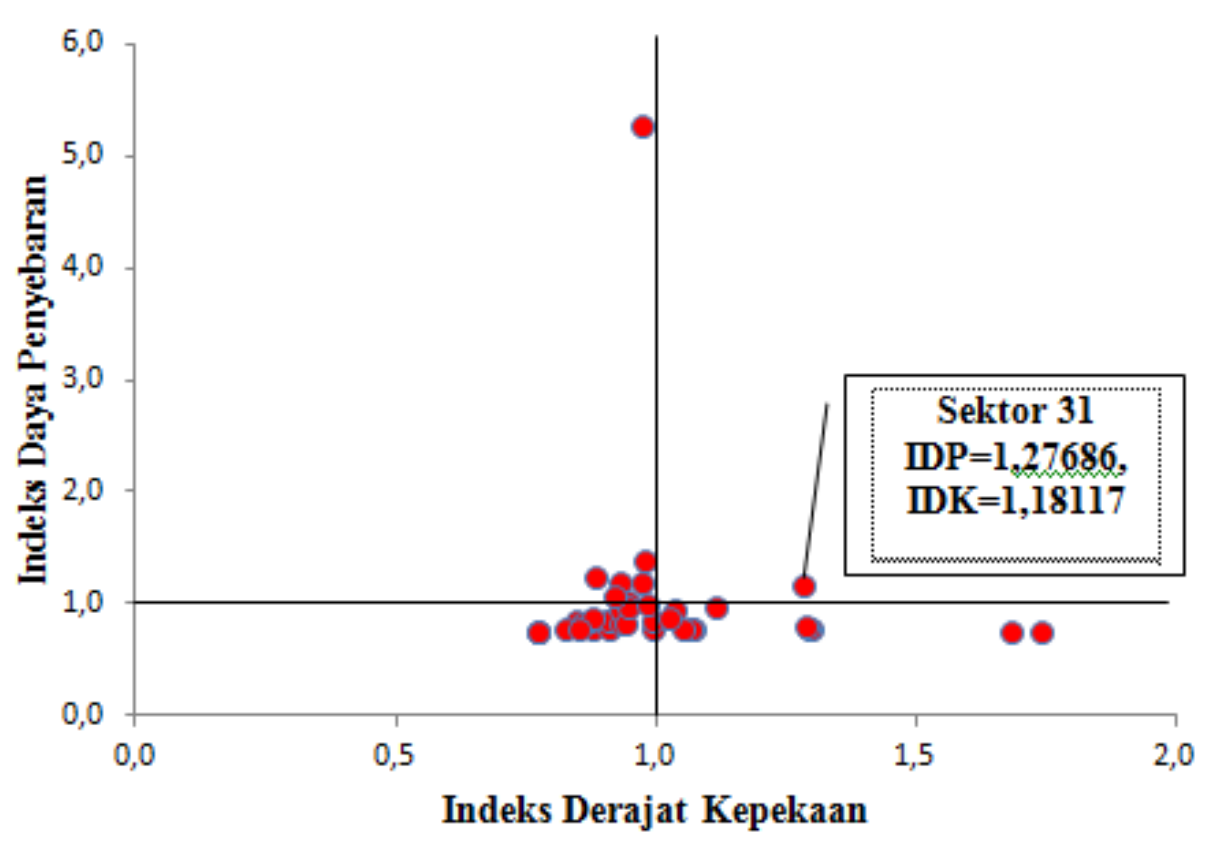

Gambar 2. Sektor Kunci Pembangunan Ekonomi di Kota Depok Tahun 2017

Keberadaan aturan yang menjadikan pengelolaan listrik diserahkan pada PLN, menjadikan kewenangan Pemkot Depok menjadi terbatas dalam mengembangkan sektor ini. Sebagai sektor yang menjadi prioritas, maka pengembangan sektor terkait listrik oleh 
Pemkot Depok dapat menyasar pada pengembangan usaha yang menghasilkan energi listrik alternatif di luar usaha yang telah dikembangkan oleh PLN. Secara umum PLN baru dapat memenuhi kebutuhan listrik sebanyak 78 persen diseluruh Indonesia (Nugraheni et al., 2018), sehingga penciptaan lapangan usaha terkait energi listrik dapat dilakukan melalui berbagai kebijakan yang dapat mendorong pengembangan energi listrik alternatif.

Sedikit berbeda dengan pengelolaan energi listrik, pengelolaan air dapat dikelola oleh pemerintah kota lewat PDAM. Secara umum pembentukan kebijakan dalam pengembangan Sektor Listrik, Gas, dan Air Minum, dapat lebih mudah dikembangkan melalui sub sektor air minum dibandingkan dengan sub sektor listrik, salah satunya dapat melalui penyertaan modal. Pengembangan sub sektor air minum dapat mendorong sektor yang menjadi suplier untuk meningkatkan kapasitas produksinya. Masih tingginya target konsumen PDAM Kota Depok yang saat ini hanya 14 persen penduduk yang memanfaatkan PDAM menjadikan potensi perkembangannya sangat besar. Pengembangan pengolahan dan distribusi air PDAM dapat menjadi pembangkit ekonomi di Kota Depok karena dapat juga mendorong sektor hulunya meningkatkan produksinya.

\section{PDRB Hijau dalam Perkembangan Wilayah}

Perkembangan wilayah Kota Depok yang struktur ekonominya didominasi sektor sekunder dan tersier, memerlukan instrumen ekonomi yang memperhatikan dampak lingkungan dari produk ekonominya. Adapun salah satu instrumen ekonomi lingkungan hidup dalam perencanaan pembangunan yaitu PDRB Hijau. Perhitungan PDRB Hijau dilakukan dengan menghitung deplesi sumberdaya alam dan degradasi lingkungan hidup, dimana pada penelitian ini didasarkan laporan yang telah disampaikan Dinas Lingkungan Hidup dan Kebersihan (DLHK) Kota Depok.

\section{Estimasi Deplesi Sumberdaya Alam}

Sumberdaya alam yang teridentifikasi digunakan dalam kegiatan ekonomi yaitu air, sehingga perhitungan deplesi sumberdaya alam didasarkan pada penggunaan air di Kota Depok.

Data jumlah unit usaha yang diperoleh dari dari BPS, BPS Provinsi Jawa Barat, BPS Kota Depok, Dinas Penanaman Modal dan Pelayanan Terpadu Satu Pintu (DPMPTSP) Kota Depok, Dinas Koperasi dan Usaha Mikro (DKUM) Kota Depok, serta acuan penggunaan air yang didasarkan pada Standar Nasional Indonesia (SNI) 19-6728.1-2002 dan berbagai penelitian terdahulu.

Adapun dalam perhitungan unit rent diperoleh dari perhitungan tarif rata-rata air dan biaya rata-rata air yang didapatkan dari PDAM Tirta Asasta Kota Depok. Selanjutnya dihitung nilai keuntungan layak berdasarkan tingkat suku bunga pada surat perbendaharaan negara tahun 2017 sebesar 5 persen, sehingga diperoleh nilai unit rent sebesar Rp.4.851. Berdasarkan hasil identifikasi penggunaan air, perhitungan deplesi sumberdaya air dilakukan pada 10 sektor ekonomi. Hasil perhitungan deplesi sumberdaya air menghasilkan nilai sebesar Rp.1.030,70 miliar (Tabel 3).

Tabel 3. Deplesi Sumberdaya Air di Kota Depok Tahun 2017

\begin{tabular}{rlr} 
No & Sektor & Nilai Deplesi (Miliar Rp) \\
\hline 1 & Pertanian & 0,97 \\
2 & Pertambangan dan Penggalian & - \\
3 & Industri Pengolahan & 718,69 \\
4 & Pengadaan Listrik dan Gas & - \\
5 & Pengadaan Air, Pengelolaan Sampah, Limbah, dan daur Ulang & - \\
6 & Konstruksi & 4,61 \\
7 & Perdagangan Besar dan Eceran : Reparasi Mobil dan Sepeda Motor & 39,47
\end{tabular}




\begin{tabular}{clr}
\hline No & Sektor & Nilai Deplesi (Miliar Rp) \\
\hline 8 & Transportasi dan Pergudangan & 0,46 \\
9 & Penyediaan Akomodasi dan Makan Minuman & 14,26 \\
10 & Informasi dan Komunikasi & - \\
11 & Jasa Keuangan dan Asuransi & 3,64 \\
12 & Real Estat & - \\
13 & Jasa Perusahaan & - \\
14 & Administrasi Pemerintahan, Pertahanan dan Jaminan Sosial Wajib & 239,61 \\
15 & Jasa Pendidikan & 4,12 \\
16 & Jasa Kesehatan dan Kegiatan Sosial & 4,87 \\
17 & Jasa Lainnya & - \\
\hline & Kota Depok & $1.030,70$ \\
\hline
\end{tabular}

Hasil perhitungan deplesi air menunjukkan bahwa sektor industri pengolahan mendominasi penggunaan air di Kota Depok. Hal ini terjadi karena sektor pertanian yang biasanya memerlukan air yang lebih banyak, aktivitas ekonominya di Kota Depok dalam jumlah sangat sedikit. Oleh karena itu, menjadikan sektor industri pengolahan sebagai sektor ekonomi terbanyak menggunakan air di Kota Depok. Keadaan ini sejalan dengan rata-rata penggunaan air di dunia pada umumnya dimana menurut Walhi (2008) dalam Faishal dan Suyono (2017), sektor industri menjadi sektor terbesar kedua yang membutuhkan air setelah sektor pertanian. Hasil ini menjadikan sektor industri pengolahan perlu diberikan prioritas dalam pembuatan kebijakan terkait pelestarian air, sehingga sumberdaya air yang menjadi bagian dalam keberlanjutan kehidupan dapat terus terjaga dan dimanfaatkan dengan baik.

\section{Estimasi Degradasi Lingkungan}

Berdasarkan identifikasi yang dilakukan dengan melihat laporan status lingkungan hidup Kota Depok, maka teridentifikasi degradasi lingkungan yang tercatat berupa degradasi udara yang dihirup sehingga berdampak pada kesehatan dan emisi $\mathrm{CO}_{2}$ yang berdampak pada peningkatan gas rumah kaca, dengan perhitungan sebagai berikut:

1. Biaya Penanggulangan Penyakit terhadap Degradasi Udara

Kualitas udara di Kota Depok diasumsikan terkait dengan jumlah penderita ISPA yang merupakan infeksi akut pada saluran pernafasan. Infeksi ISPA berlangsung selama 14 hari sebagai batas yang diambil untuk menunjukkan proses akut (Pratiwi dan Wahyuni, 2016). Sehingga perhitungan biaya penyakit diperoleh dengan menjumlahkan biaya penyembuhan dan pendapatan yang hilang selama 14 hari didasarkan pada UMR Kota Depok tahun 2017. Diperoleh total biaya penyakit sebesar Rp.300,21 miliar (Tabel 4).

Tabel 4. Biaya Penanggulangan Penyakit di Kota Depok Tahun 2017

\begin{tabular}{lr}
\hline \multicolumn{1}{c}{ Keterangan } & Jumlah (Miliar Rp) \\
\hline Total biaya penyembuhan & 55,63 \\
Total pendapatan yang hilang & 244,58 \\
\hline Total biaya penanggulangan penyakit & 300,21 \\
\hline
\end{tabular}

2. Biaya Pengganti Emisi $\mathrm{CO}_{2}$

Perhitungan emisi $\mathrm{CO}_{2}$ dilakukan dengan mengukur penggunaan energi yang terjadi di Kota Depok berdasarkan data berupa konsumsi listrik, konsumsi gas cair dan BBM. Berdasarkan pada faktor emisi di Indonesia yang ditetapkan oleh Energy Information Administration (EIA), maka diperoleh total emisi $\mathrm{CO}_{2}$ di Kota Depok tahun 2017 sebesar 1.365.651,43 ton (Tabel 5). 
Tabel 5 Emisi $\mathrm{CO}_{2}$ di Kota Depok Tahun 2017

\begin{tabular}{lrccr}
\hline \multicolumn{1}{c}{ Jenis Energi } & \multicolumn{2}{c}{ Konsumsi Energi } & $\begin{array}{c}\text { Faktor Emisi } \\
\text { Berdasarkan EIA }\end{array}$ & Emisi CO $_{2}$ (Ton) \\
\hline Listrik & $2.474 .488 .084,00$ & $\mathrm{kWh}$ & $454 \mathrm{gr} \mathrm{CO} 2 / \mathrm{kWh}$ & $1.123 .417,59$ \\
Gas Cair & $80.119 .200,00$ & $\mathrm{~kg}$ & $3 \mathrm{~kg} \mathrm{CO} 2 / \mathrm{kg}$ & $240.357,60$ \\
Bensin & $738.744 .872,44$ & liter & $2,3 \mathrm{gr} \mathrm{CO} 2 / \mathrm{liter}$ & $1.699,11$ \\
Solar & $65.604 .177,32$ & liter & $2,7 \mathrm{gr} \mathrm{CO} 2 / \mathrm{liter}$ & 177,13 \\
\hline Total & & & & $1.365 .651,43$ \\
\hline
\end{tabular}

Sumber: Energy Information Administration (2000) dalam Edyanto (2013)

Hasil emisi $\mathrm{CO}_{2}$ dapat dikonversikan ke dalam nilai mata uang dengan mengasumsikannya pada kebutuhan akan hutan kota sebagai penyerap $\mathrm{CO}_{2}$, dimana setiap satu hektar hutan kota dapat menyerap 64 ton $\mathrm{CO}_{2}$ dan selanjutnya menyesuaikannya juga pada kebutuhan pendanaan hutan kota (Bahtiar, 2018). Dengan mempertimbangkan keberadaan hutan kota saat ini, maka kebutuhan pendanaan hutan kota sebagai bagian mengatasi dampak negatif Gas Rumah Kaca pada tahun 2017 sebesar Rp.1.279,87 miliar. Berarti secara keseluruhan penanganan degradasi lingkungan di Kota Depok diperkirakan sebesar Rp. 1.580,08 miliar, seperti diperlihatkan Tabel 6.

Tabel 6 Estimasi Nilai Degradasi Lingkungan di Kota Depok Tahun 2017

\begin{tabular}{lr}
\hline \multicolumn{1}{c}{ Keterangan } & Jumlah (Miliar Rp) \\
\hline Biaya Penanggulangan Penyakit & 300,21 \\
Biaya Emisi & $1.279,87$ \\
\hline Total Estimasi Nilai Degradasi Lingkungan & $1.580,08$ \\
\hline
\end{tabular}

\section{Perhitungan PDRB Hijau}

Hasil perhitungan PDRB hijau seperti terlihat pada Tabel 7, menunjukkan angka sebesar Rp.55.733,71 miliar atau memiliki selisih sebesar Rp.2.610,78 miliar (Rp.1.030,70 miliar + Rp.1.580,08 miliar), memperlihatkan persentase yang kecil atau hanya sebesar 4,47 persen dibandingkan PDRB Coklat. Namun apabila disandingkan dengan realisasi pedapatan Kota Depok di tahun 2017 yang sebesar Rp.2.847,40 miliar, maka pengalokasian kebutuhan pemeliharaan kualitas maupun penanggulangan masalah lingkungan hanya menyisakan realisasi pendapatan sebesar Rp.236,62 miliar. Nilai ini tidak mencukupi untuk alokasi belanja pegawai Pemkot Depok tahun 2017 sebesar Rp.306,98 miliar.

Lebih jauh lagi memandang suatu daerah yang dianggap mampu dalam pembiayaan pembangunan, apabila total realisasi pendapatan lebih besar daripada total realisasi belanja dan total realisasi PAD lebih besar daripada total realisasi belanja rutin (Nugroho, 2012). Dengan nilai PAD Kota Depok tahun 2017 sebesar Rp.1.210,75 miliar, maka beban akan mitigasi dampak masalah lingkungan hidup akan menyerap seluruh pendapatan. Akibatnya, Kota Depok hanya mampu membiayai pembangunan daerahnya jika mendapatkan pendanaan dari luar kota. Kebijakan yang bersifat pencegahan terhadap dampak lingkungan akan lebih efisien dibandingkan hanya melalui upaya penanggulangan kerusakan. Kondisi ini menjadikan kebutuhan akan penanganan lingkungan lewat pencegahan penggunaan sumberdaya alam yang berlebih dan kerusakan alam menjadi tanggung jawab seluruh stakeholder di Kota Depok. Keikutsertaan dalam menjaga lingkungan, baik itu atas dasar kesadaran sendiri maupun melalui berbagai kebijakan pengenaan biaya terkait lingkungan dapat diterapkan untuk mencegah dampak yang akan muncul. 
Tabel 7 PDRB Hijau Kota Depok Tahun 2017

\begin{tabular}{lr}
\hline \multicolumn{1}{c}{ Keterangan } & \multicolumn{1}{c}{$\begin{array}{c}\text { Jumlah } \\
\text { (Miliar Rp) }\end{array}$} \\
\hline PDRB Coklat & $58.344,49$ \\
Deplesi Sumberdaya Alam & $1.030,70$ \\
Degradasi Lingkungan & $1.580,08$ \\
\hline PDRB Hijau & $55.733,71$ \\
\hline
\end{tabular}

PDRB hijau dapat digunakan sebagai indikator kinerja Pemkot Depok sehingga tidak hanya mengejar pertumbuhan ekonomi namun juga memperhatikan dampaknya terhadap lingkungan. Perhitungan PDRB hijau secara kuantitatif dapat digunakan sebagai ukuran untuk mewujudkan prinsip pembangunan berkelanjutan di Kota Depok. Salah satu prinsip tersebut berupa terpenuhinya kebutuhan hidup dasar (Hadi, 1998 dalam Sriyanto, 2007). Adapun pemenuhan kebutuhan dasar memiliki korelasi positif dengan indeks kualitas lingkungan (Suryani, 2018). Berarti bahwa adanya kenaikan kualitas lingkungan hidup Kota Depok akan meningkatkan pemenuhan kebutuhan dasar. Oleh karena itu, pengembangan wilayah berwawasan lingkungan di Kota Depok dilakukan untuk mewujudkan peningkatan kualitas lingkungan.

Perubahan nilai selisih PDRB coklat dan PDRB hijau yang dihitung tiap tahun dapat digunakan untuk mengukur keberhasilan dari kebijakan terkait lingkungan hidup yang telah dijalankan. Selisih nilai PDRB juga dapat dijadikan panduan dalam menyusun target penerimaan daerah yang akan digunakan untuk membiayai mitigasi kerusakan lingkungan.

Memperhatikan hasil analisis yang telah dilakukan, maka pengembangan wilayah berwawasan lingkungan di Kota Depok dapat dilakukan melalui mitigasi kerusakan lingkungan yang setara dengan selisih PDRB coklat dan PDRB hijau sebesar Rp. 2.610,78 miliar, meliputi:

1. Pengembangan wilayah dengan memperhatikan kualitas lingkungan, melalui mitigasi kerusakan lingkungan berupa pengolahan sampah dengan membangun fasilitas layanan kebersihan sampah dan pengembangan Energi Baru Terbarukan (EBT) berupa Pembangkit Listrik Tenaga Sampah (PLTSa). Menurut Safrizal (2014), potensi energi listrik di TPA Cipayung Kota Depok dapat mencapai 21,91 Mega Watt. Pengembangan PLTSa tidak hanya dapat meningkatkan perekonomian wilayah karena mengembangkan sektor kunci atau sektor pemimpin pembangunan ekonomi, namun juga dapat mengurangi permasalahan terkait pengelolaan sampah. Upaya ini juga untuk pengurangan emisi karena mengalihkan penggunaan energi fosil, sebagai bentuk mitigasi kerusakan lingkungan yang dapat dilakukan di Kota Depok.

2. Pengembangan wilayah dengan memperhatikan sumberdaya alam yang dapat dilakukan melalui revitalisasi situ. Revitalisasi situ dilakukan karena melihat keadaan rumah tangga di Kota Depok yang memiliki akses air bersih dan memilih menggunakan sumber air tanah mencapai 45,56 persen (Pemkot Depok, 2016). Pengambilan air tanah secara berlebihan dapat menyebabkan terjadinya penurunan permukaan air tanah (Wulandari et al., 2017). Oleh karena itu, revitalisasi situ dapat dilakukan sebagai salah satu upaya menciptakan sumber air baku baru yang dikelola PDAM. Pendistribusian air situ kepada penduduk diharapkan dapat mengalihkan penggunaan air tanah sehingga mencegah penurunan permukaan air tanah di Kota Depok.

\section{KESIMPULAN}

Perkembangan wilayah di Kota Depok memperlihatkan bahwa 65,08 persen kelurahan di Kota Depok berada pada tingkat perkembangan hirarki III yang selanjutnya ditetapkan sebagai wilayah hinterland, sedangkan kelurahan lainnya dapat ditetapkan 
sebagai wilayah inti yang sebagian besarnya berkumpul di sekitar wilayah strategis ekonomi.

Hasil analisis keterkaitan ke belakang (backward lingkage) diketahui bahwa sektor penyedia input sebagian besar berhubungan dengan sektor perdagangan, sedangkan melalui nilai keterkaitan ke depan (forward lingkage) menunjukkan bahwa sektor pengguna input, banyak terhubung dengan sektor listrik, gas dan air minum. Namun, sektor listrik, gas, dan air minum yang hanya dapat ditetapkan sebagai sektor kunci pembangunan ekonomi Kota Depok.

Nilai PDRB hijau di Kota Depok tahun 2017 sebesar Rp.55.733,71 milar, selisih sebesar Rp.2.610,78 miliar atau 4,47 persen lebih rendah daripada PDRB Coklat yang sebesar Rp.58.344,49 miliar. Selisih nilai PDRB tersebut dibandingkan dengan PAD yang hanya Rp.1.210,75 miliar akan mengurangi seluruh pendapatan murni Kota Depok. PDRB hijau lebih relevan untuk dijadikan indikator ekonomi dalam pengembangan wilayah karena lebih menggambarkan nilai kesejahteraan seutuhnya. Melalui perhitungan PDRB hijau, arahan pengembangan wilayah yang berwawasan lingkungan dapat memperhatikan keberadaan sumberdaya alam dan kerusakan lingkungan.

\section{DAFTAR PUSTAKA}

[BPS] Badan Pusat Statistik. 2018. Produk Domestik Regional Bruto Provinsi-Provinsi di Indonesia Menurut Lapangan Usaha. Jakarta (ID): Badan Pusat Statistik.

[BPS Kota Depok] Badan Pusat Statistik Kota Depok. 2017. Produk Domestik Regional Bruto Menurut Lapangan Usaha Kota Depok 2012-2016. Depok (ID) : BPS Kota Depok.

Bahtiar R. 2018. Perhitungan PDRB Lingkungan Hidup: Studi Kasus Perhitungan PDRB LH Kota Bogor. Bahan Presentasi. Dalam: Training PDRB Hijau di IPB International Certified Training Bogor, 24-26 September.

Darlen MF, Hadi S, Ardiansyah M. 2015. Pengembangan Wilayah Berbasis Potensi Unggulan di Kabupaten Manggarai Timur Provinsi NTT sebagai Daerah Otonom Baru. Jurnal Tata Loka. 17 (1): 37-52.

Daryanto A, Hafizrianda Y. 2013. Analisis Input-Output \& Social Accounting Matrix untuk Pembangunan Ekonomi Daerah. Bogor (ID): IPB Press.

Edyanto CBH. 2013. Emisi Karbon Sebagai Dasar Implementasi Penyediaan Ruang Terbuka Hijau di DKI Jakarta. Jurnal Sains dan Teknologi Indonesia. 15(1): 1-7.

Faishal A, Suyono. 2013. Evaluasi Ketersediaan dan Kebutuhan Air untuk Pertanian Daerah Irigasi Boro Kabupaten Purworejo Provinsi Jawa Tengah. Jurnal Bumi Indonesia. 2 (4): 1-11.

Hifdziyah L. 2011. Analisis Penurunan Kualitas Lingkungan di Sekitar Tempat Pembuangan Akhir Sampah Galuga Kabupaten Bogor Jawa Barat [skripsi]. Bogor (ID): Institut Pertanian Bogor.

Ismiyati, Marlita D, Saidah D. 2014. Pencemaran Udara Akibat Emisi Gas Buang Kendaraan Bermotor. Jurnal Manajemen Transportasi \& Logistik. 15 (2): 85-93.

[KLHK] Kementerian Lingkungan Hidup dan Kehutanan. 2017. Indeks Kualitas Lingkungan Hidup Indonesia 2016. Jakarta (ID): Kementerian Lingkungan Hidup dan Kehutanan.

Mulya Y, Adi ISP, Supani SS. 2014. Valuasi Ekonomi Lingkungan Perkotaan Indonesia dalam Pengukuran PDRB Hijau: Studi Kasus Pada Kota Bogor [Internet]. [Diunduh pada 14 Mei 2018]. Tersedia pada: https://www.researchgate.net/publication/303248516.

Nugraheni W, Negoro NP, Syafi'i M. 2018. Identifikasi Faktor Keberhasilan Pengelolaan Distribusi Retail Energi Listrik di PLN Unit Layanan Salatiga. Jurnal Teknik ITS. 7 (1): 36-39.

Nugroho RH. 2012. Analisa Keuangan Daerah dalam Pengelolaan Anggaran Pendapatan dan Belanja Daerah (Studi di Kabupaten Lombok Tengah). Prosiding Seminar Nasional \& Call for Paper FMI ke-4. 13-14 November 2012; Yogyakarta, Indonesia. Yogyakarta (ID). Forum Manajemen Indonesia; pp. 804-821.

Paramita D. 2018. Kajian dan Arahan Pengelolaan Sampah Berdasarkan Kemampuan Daya Dukung dan Kapasitas Tampung Kota Depok [tesis]. Bogor (ID): Institut Pertanian Bogor.

[Pemkot Depok] Pemerintah Kota Depok. 2016. Rencana Pembangunan Jangka Menengah Daerah Kota Depok 2016-2021. Depok (ID): Pemerintah Kota Depok.

Pratiwi A, Wahyuni EG. 2016. Sistem Pakar Diagnosis ISPA pada Balita Dengan Metode Certainty Factor. Prosiding Seminar Nasional Informatika Medis VII; Yogyakarta 6 Agustus 2016. Yogyakarta (ID): Magister Teknik Informatika Universitas Islam Indonesia hlm 42-53. 
Putra W. 2013. Model Perhitungan Besaran PDRB Hijau Sektor Kehutanan di Kalimantan Barat Melalui Pendekatan Jasa Lingkungan. Jurnal Eksos. 9 (1): 49-68.

Ratnaningsih M, Apriliani AT, Sudharto D, Suparmoko M. 2006. PDRB Hijau. Yogyakarta (ID) : BPFEYogyakarta. Perencanaan Pengembangan Wilayah. Bogor (ID): Institut Pertanian Bogor.

Rustiadi E, Panuju DR. 2013. Teknik Analisis Perencanaan Pengembangan Wilayah. Bogor (ID): Institut Pertanian Bogor.

Safrizal. 2014. Distributed Generation Pembangkit Listrik Tenaga Sampah Kota (PLTSa) Type Incinerator Solusi Listrik Alternatif Kota Medan. Prosiding Seminar Nasional Teknologi dan Informatika I; Kudus 1 Agustus 2014. Kudus (ID): Fakultas Teknik Universitas Muria Kudus hlm 121-128.

Sriyanto. 2007. Kondisi Lingkungan Hidup di Jawa Tengah dan Prospek Pembangunan ke Depan. Jurnal Geografi. 4 (2): 107-113.

Sudarya D, Sitorus SRP, Firdaus M. 2013. Analisis Perkembangan Ekonomi Wilayah Untuk Arahan Pembangunan Kecamatan di Wilayah Pesisir Kabupaten Garut. Jurnal Ilmiah Geomatika. 19 (2): 134140.

Suparmoko M, Sudirman D, Setyarko Y, Wibowo HS. 2014. Valuasi Ekonomi Sumberdaya Alam \& Lingkungan. Yogyakarta (ID): BPFE-Yogyakarta.

Suryani AS. 2018. Pengaruh Kualitas Lingkungan terhadap Pemenuhan Kebutuhan Dasar di Provinsi Banten. Jurnal Aspirasi. 9 (1): 34-62.

Tampuyak S, Anwar C, Sangadji MN. 2016. Analisis Proyeksi Pertumbuhan Penduduk dan Kebutuhan Fasilitas Persampahan di Kota Palu. Jurnal Katalogis. 4 (4): 94-104.

Utama MS. 2009. Integrasi Antara Aspek Lingkungan dan Ekonomi Dalam Penghitungan PDRB Hijau pada Sektor Kehutanan di Kabupaten Karangasem Provinsi Bali. Jurnal Bumi Lestari. 9 (2): 129-137.

Wibisono AF, Dewi P. 2014. Sosialisasi Bahaya Membunag Sampah Sembarangan dan Menentukan Lokasi TPA Di Dusun Deles Desa Jagonayan Kecamatan Ngablak. Jurnal Inovasi dan Kewirausahaan. 3 (1): 2127.

World Bank. 2009. Investing in a More Sustainable Indonesia. Wahington DC (US): The World Bank Group.

Wulandari D, Abdullah F, AlRasyid MK. 2017. Intensifikasi Eksplorasi Sumber Mata Air sebagai Upaya Pencegahan Penurunan Muka Air Tanah Kota Bandung. Prosiding Seminar Nasional Kebumian ke-10; Yogyakarta 13-14 September 2017. Yogyakarta (ID): Universitas Gadjah Mada hlm 131-138. 